\title{
Changes in the Free Amino Acid Content of the Shucked Oyster Crassostrea gigas Stored in Salt Water at $3^{\circ} \mathrm{C}$
}

\author{
Shota Tanimoto $^{1 *}$, Koji Kawakami ${ }^{2}$ and Satoshi Morimoto ${ }^{3}$ \\ ${ }^{1}$ Faculty of Human Culture and Science, Prefectural University of Hiroshima, Hiroshima 734-8558, Japan \\ ${ }^{2}$ Satake Co., Ltd., Hiroshima 739-8602, Japan \\ ${ }^{3}$ Ehime Institute of Industrial Technology, Ehime 791-1101, Japan
}

\begin{abstract}
Shucked oysters were soaked in an equal weight of salt water and stored at $3^{\circ} \mathrm{C}$ for 7 days. Changes in the free amino acid content of the whole body and in the adductor muscle were evaluated by a practical distribution method. With the exception of aspartic acid and tyrosine, no significant changes in free amino acids or ammonia were observed in whole-body shucked oysters during the storage period. In contrast, the majority of free amino acids in the adductor muscle decreased significantly. Most of these free amino acids were detected in considerable amounts in the surrounding salt water after 7 days of storage. Both the weight of the whole body and the salinity of the surrounding salt water decreased significantly during the storage period. These results suggest that free amino acids were eluted from the cutting surface of the adductor muscle and indicate that the free amino acid content per shucked oyster and in the adductor muscle, decreases during cold storage.
\end{abstract}

Key words: Pacific oyster, Shucked oyster, Free amino acids, Glycogen, Cold storage

\section{Introduction}

The Pacific oyster Crassostrea gigas is the primary oyster species supporting the worldwide shellfish industry. This oyster is also one of the most popular shellfish in Japan. Both the shelled and the shucked (whole-body) oysters are delivered to consumers under cold storage. The bodies of the shucked oysters are inherently weak and are commonly soaked in salt water prior to commercial use in Japan. Shinkawa (1988) showed that the ciliary movement of the shucked oyster gills remains active for up to 6 days in salt water at $10^{\circ} \mathrm{C}$. This result suggests that the shucked oysters are alive for at least part of the shipping period.

Changes in the levels of ATP-related compounds and organic acids were observed in the shucked oysters that had been stored in salt water at $3^{\circ} \mathrm{C}$ for 10 days (Tanimoto et al., 2004). The most useful freshness indicators for whole-body shucked oysters are the adenylate energy charge, defined as $(\mathrm{ATP}+1 / 2 \mathrm{ADP}) /(\mathrm{ATP}+\mathrm{ADP}+\mathrm{AMP})$, and the levels of succinic and acetic acids. Acetate was the best freshness indicator for the adductor muscle. The flesh of marine bivalves contains high levels of nonprotein nitrogenous compounds (Konosu and Yamaguchi, 1982) including free amino acids (FAAs). FAAs are abundant in shellfish and are important contributors to their bioactivity and meaty flavor (Hashimoto, 1965; Wu, 2009,2010 ). In addition, in many bivalves, including oysters, the relative levels of these compounds change in response to changes in osmotic pressure and/or anaerobic conditions due to habitat fluctuations (Lynch and Wood, 1966; Kluytmans et al., 1977; Heavers and Hammen, 1985; Isani et al., 1995; Enomoto et al., 1996; Hosoi et al., 2003; Rafrafi and Uglow, 2009).
Open Access http://dx.doi.org/10.5657/FAS.2013.0063

This is an Open Access article distributed under the terms of the Creative Commons Attribution Non-Commercial License (http://creativecommons. org/licenses/by-nc/3.0/) which permits unrestricted non-commercial use, distribution, and reproduction in any medium, provided the original work is properly cited. pISSN: 2234-1749 eISSN: 2234-1757
Received 27 February 2013; Revised 4 April 2013

Accepted 4 April 2013

*Corresponding Author

E-mail: s-tanimoto@pu-hiroshima.ac.jp 
To date, changes in FAA levels in live shellfish have been reported for scallops (Enomoto et al., 1996), hard clams (Chiou et al., 1998), and small abalones (Chiou et al., 2002). Murata and Sakaguchi (1986) also showed changes in the levels of FAAs, trimethylamine, and nonprotein nitrogen in the bodies and adductor muscles of shucked oysters that were stored on ice but not soaked in seawater. Specifically, taurine and glycine levels showed little change, alanine levels increased slightly, and proline and glutamic acid levels in whole-body oysters decreased during storage. However, changes in FAA levels in shucked oysters that had been soaked in salt water remained unclear.

With respect to nutritional reserves, carbohydrates play an important role in the energy production of most bivalves (Zandee et al., 1980; Uzaki et al., 2003; Patrick et al., 2006). Glycogen is the most important compound for energy production, and it is used by several shellfish under anaerobic conditions (Ogunsua et al., 1990; Isani et al., 1995; Chiou et al., 1998). Thus, glycogen is likely utilized by shucked oysters during cold storage.

The current study examines changes in FAA levels in whole-body oysters and in the adductor muscles of oysters stored at $3^{\circ} \mathrm{C}$ under the general shipping conditions used for shucked oysters up to the best-before date (7 days). Changes in glycogen content, water content, and whole-body weight were also monitored.

\section{Materials and Methods}

\section{Preparation of the shucked oysters}

Fifty shelled oysters were purchased from an oyster farmer in Ainan-cho, Ehime Prefecture, Japan. The oysters were prepared by a technician skilled in shucking oysters and transferred on ice to the laboratory within $1 \mathrm{~h}$.

\section{Storage of shucked oysters}

Whole-body shucked oysters were rinsed with ice-cold seawater. Two or five oysters were inserted into plastic bottles $(100 \mathrm{~mL})$ with an equal weight of ice-cold seawater. This is a common means of storage in Japanese commercial markets. The bottles were stored at $3 \pm 2^{\circ} \mathrm{C}$ for 7 days.

\section{FAAs and ammonia}

Five grams of chopped whole-body shucked oysters from four individuals, and $2.5 \mathrm{~g}$ of chopped adductor muscle from six individuals, were used for amino acid analyses. The samples were homogenized with $10 \mathrm{~mL}$ and $5 \mathrm{~mL}$ of $10 \%$ trichloroacetic acid (TCA), respectively, followed by centrifugation at $10,000 \mathrm{~g}$ for $15 \mathrm{~min}$. The residues were extracted twice with the same volumes of 5\% TCA. Supernatants of the whole-body and adductor muscle samples were collected and diluted up to 50 and $25 \mathrm{~mL}$ with 5\% TCA, respectively. In addition, $2 \mathrm{~mL}$ of the salt water that had been used for soaking the shucked oysters for 7 days was vortexed with $1 \mathrm{~mL}$ of $15 \%$ TCA. The mixtures were then centrifuged at $10,000 \mathrm{~g}$ for 15 min. The supernatants were collected and used in amino acid analyses. All samples were stored at $-80^{\circ} \mathrm{C}$ until analysis. A series of procedures was performed at ice-water temperatures. The frozen supernatant was melted and diluted twice with 0.2 $\mathrm{N} \mathrm{HCl}$. Ten microliters of the diluted solution was used for analyses of FAAs and ammonia in an L-8900 amino acid analyzer (Hitachi High-Technologies Co., Tokyo, Japan).

\section{Glycogen}

The glycogen content of the oyster samples was measured as described previously (Da Silva and Zancan, 1994; Okumura et al., 2002). A 2.5-g sample of chopped flesh obtained from four shucked oysters was homogenized with $5 \mathrm{~mL}$ of $30 \%$ $\mathrm{KOH}$ in a centrifugation tube. The tube was heated in a water bath (SJ-10; Taitec Co., Ltd.) until the oysters dissolved. After the tube was cooled, $10 \mathrm{~mL}$ of ethanol was added to the dissolved sample. Glycogen that had flocculated in the tube was separated by centrifuging the sample at 3,000 $\mathrm{g}$ for $15 \mathrm{~min}$. The precipitate was dissolved in $1.5 \mathrm{~mL}$ of distilled water and a new precipitate was generated by the addition of one drop of saturated $\mathrm{KCl}$ solution and $25 \mathrm{~mL}$ of $99 \%$ ethanol. This procedure was repeated twice. Two milliliter of water and 1 $\mathrm{mL}$ of $2 \mathrm{~N} \mathrm{H}_{2} \mathrm{SO}_{4}$ were added to the collected precipitate after evaporation of ethanol in a hot bath (LB-160; Toyo Roshi Kaisha, Ltd., Tokyo, Japan) followed by heating in a boiling water bath (SJ-10; Taitec Co., Ltd., Saitama, Japan) for $2.5 \mathrm{~h}$. After the solution was cooled and neutralized, it was diluted with distilled water up to a volume of $25 \mathrm{~mL}$. The glucose content of the solution was measured with a glucose test kit (GlucoseCII-test-Wako; Wako Pure Chemical Industries Ltd., Osaka, Japan). The glycogen content in the oysters was determined by multiplying the glucose concentration by 0.9 .

\section{Moisture content of the shucked oysters}

Approximately $2.5 \mathrm{~g}$ of chopped flesh from the whole bodies of four oysters was used to determine moisture content. Water content was measured by comparing the wet weight to the constant weight obtained after oven-drying at $120^{\circ} \mathrm{C}$ (Hosoi et al., 2003).

\section{Weight of shucked oysters}

Five bottles, each containing two shucked oysters, were used to measure the weight of the shucked oysters. Weight was measured throughout the storage period by withdrawing the oysters and draining the surrounding salt water. Changes in weight are expressed as a percentage of the initial weight. 


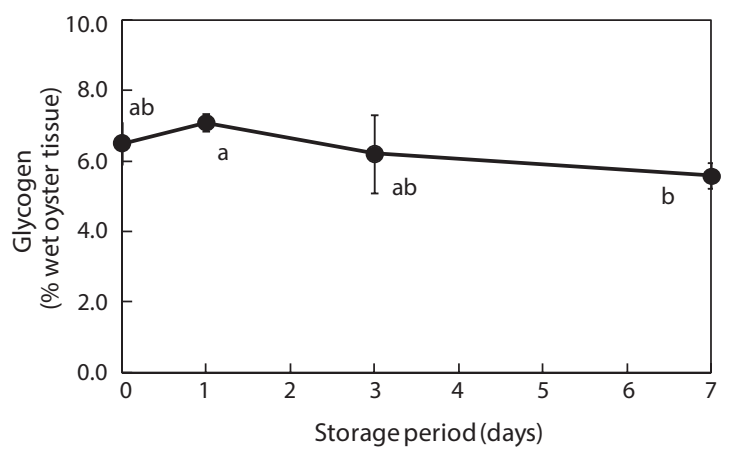

Fig. 1. Glycogen level of the whole body of oysters during storage at $3^{\circ} \mathrm{C}$. Different letters indicate significant differences $P<0.05$ ). The vertical bars represent the standard deviations $(n=3)$.

\section{Salinity of the salt water used for soaking}

The chloride ion content of the salt water used for soaking the shucked oysters during storage was determined by Mohr's volumetric method (Blaedel and Meloche, 1960). Salinity was calculated based on the concentration of chloride ions.

\section{Statistical analyses}

All measurements were performed independently on three specimens with the exception of weight change, which was determined using five specimens. Analyses were performed using Excel Tokei 2010 statistical software (SSRI Co. Ltd., Tokyo, Japan). Tukey's multiple range tests were applied to evaluate the significance of differences among the mean values. The significance level was set to $5 \%$ in all analyses.

\section{Results}

Glycogen content of the whole-body oysters changed during the storage period (Fig. 1). Prior to storage, the mean glycogen level was $6.5 \%$. After 7 days of storage, the glycogen level had dropped significantly to $5.6 \%$.

The total amount of FAAs before storage was 2,702.3 $\mathrm{mg} / 100 \mathrm{~g}$ of whole-body oyster (Table 1 ). The whole body contained relatively high levels of taurine, proline, glutamic acid, alanine, and glycine, which were 1455.3, 254.0, 180.9, 140.7 , and $126.4 \mathrm{mg} / 100 \mathrm{~g}$, respectively. Changes in ammonia levels were not significant and among the FAAs only aspartic acid, tyrosine, and alanine showed any evidence of change.

Table 1. Changes in free amino acids and ammonia in the whole body of shucked oyster during storage at $3^{\circ} \mathrm{C}(\mathrm{mg} / 100 \mathrm{~g})$

\begin{tabular}{|c|c|c|c|c|}
\hline \multirow{2}{*}{ Amino acids } & \multicolumn{4}{|c|}{ Storage period (days) } \\
\hline & $\mathbf{0}$ & 1 & 3 & 7 \\
\hline Taurine & $1,455.3 \pm 15.4^{\mathrm{a}}(100)$ & $1,427.4 \pm 39.7^{\mathrm{a}}(98)$ & $1,476.8 \pm 39.0^{\mathrm{a}}(101)$ & $1,446.1 \pm 3.4^{\mathrm{a}}(99)$ \\
\hline Aspartic acid & $77.2 \pm 3.1^{\mathrm{a}}(100)$ & $76.4 \pm 4.0^{\mathrm{a}}(99)$ & $67.6 \pm 6.1^{\mathrm{ab}}(88)$ & $62.4 \pm 3.4^{\mathrm{b}}(81)$ \\
\hline Threonine & $45.7 \pm 3.1^{\mathrm{a}}(100)$ & $58.4 \pm 7.2^{\mathrm{a}}(128)$ & $48.9 \pm 14.8^{\mathrm{a}}(107)$ & $46.7 \pm 5.6^{\mathrm{a}}(102)$ \\
\hline Serine & $31.8 \pm 1.1^{\mathrm{a}}(100)$ & $32.6 \pm 4.5^{\mathrm{a}}(102)$ & $28.1 \pm 3.8^{\mathrm{a}}(88)$ & $28.0 \pm 2.2^{\mathrm{a}}(88)$ \\
\hline Glutamic acid & $180.9 \pm 9.9^{\mathrm{a}}(100)$ & $191.9 \pm 11.5^{\mathrm{a}}(106)$ & $175.5 \pm 5.6^{\mathrm{a}}(97)$ & $170.8 \pm 15.1^{\mathrm{a}}(94)$ \\
\hline Proline & $254.0 \pm 14.0^{\mathrm{a}}(100)$ & $231.6 \pm 17.9^{\mathrm{a}}(91)$ & $256.9 \pm 22.3^{\mathrm{a}}(101)$ & $252.5 \pm 14.4^{\mathrm{a}}(99)$ \\
\hline Glycine & $126.4 \pm 4.6^{\mathrm{a}}(100)$ & $91.1 \pm 2.6^{\mathrm{a}}(72)$ & $104.9 \pm 29.8^{\mathrm{a}}(83)$ & $116.0 \pm 12.7^{\mathrm{a}}(92)$ \\
\hline Alanine & $140.7 \pm 9.8^{\mathrm{a}}(100)$ & $163.2 \pm 20.2^{\mathrm{a}}(116)$ & $164.4 \pm 11.2^{\mathrm{a}}(117)$ & $172.4 \pm 5.2^{\mathrm{a}}(122)$ \\
\hline Valine & $13.3 \pm 0.8^{\mathrm{a}}(100)$ & $14.3 \pm 2.5^{\mathrm{a}}(108)$ & $14.5 \pm 3.3^{\mathrm{a}}(109)$ & $13.2 \pm 0.5^{\mathrm{a}}(99)$ \\
\hline Cystine & $1.7 \pm 0.4^{\mathrm{a}}(100)$ & $1.4 \pm 0.0^{\mathrm{a}}(79)$ & $1.6 \pm 0.2^{\mathrm{a}}(90)$ & $1.3 \pm 0.1^{\mathrm{a}}(77)$ \\
\hline Methionine & $14.1 \pm 1.3^{\mathrm{a}}(100)$ & $14.9 \pm 1.5^{\mathrm{a}}(105)$ & $14.6 \pm 1.7^{\mathrm{a}}(103)$ & $17.7 \pm 3.7^{\mathrm{a}}(125)$ \\
\hline Isoleucine & $8.2 \pm 0.5^{\mathrm{a}}(100)$ & $8.6 \pm 1.2^{\mathrm{a}}(105)$ & $8.9 \pm 2.0^{\mathrm{a}}(109)$ & $8.3 \pm 0.3^{\mathrm{a}}(101)$ \\
\hline Leucine & $16.0 \pm 1.0^{\mathrm{a}}(100)$ & $17.0 \pm 2.0^{\mathrm{a}}(106)$ & $17.2 \pm 4.5^{\mathrm{a}}(107)$ & $15.2 \pm 1.4^{\mathrm{a}}(95)$ \\
\hline Tyrosine & $8.7 \pm 0.8^{\mathrm{a}}(100)$ & $10.2 \pm 1.2^{\mathrm{ab}}(117)$ & $9.9 \pm 0.8^{\mathrm{ab}}(114)$ & $12.0 \pm 1.0^{\mathrm{b}}(138)$ \\
\hline Phenylalanine & $6.5 \pm 1.1^{\mathrm{a}}(100)$ & $5.5 \pm 0.4^{\mathrm{a}}(85)$ & $6.2 \pm 0.8^{\mathrm{a}}(97)$ & $6.4 \pm 1.2^{\mathrm{a}}(100)$ \\
\hline$\beta$-Alanine & $50.3 \pm 5.0^{\mathrm{a}}(100)$ & $39.9 \pm 1.6^{\mathrm{a}}(79)$ & $42.1 \pm 5.2^{\mathrm{a}}(84)$ & $39.6 \pm 4.6^{\mathrm{a}}(79)$ \\
\hline Ammonia & $4.1 \pm 0.5^{\mathrm{a}}(100)$ & $3.8 \pm 0.2^{\mathrm{a}}(92)$ & $3.5 \pm 0.4^{\mathrm{a}}(85)$ & $4.1 \pm 0.1^{\mathrm{a}}(100)$ \\
\hline Lysine & $18.3 \pm 0.6^{\mathrm{a}}(100)$ & $22.7 \pm 4.6^{\mathrm{a}}(124)$ & $23.4 \pm 5.2^{\mathrm{a}}(128)$ & $20.9 \pm 6.8^{\mathrm{a}}(114)$ \\
\hline Histidine & $29.9 \pm 5.7^{\mathrm{a}}(100)$ & $32.7 \pm 6.1^{\mathrm{a}}(109)$ & $32.8 \pm 5.7^{\mathrm{a}}(110)$ & $28.8 \pm 1.3^{\mathrm{a}}(96)$ \\
\hline Arginine & $76.5 \pm 9.0^{\mathrm{a}}(100)$ & $61.5 \pm 19.7^{\mathrm{a}}(81)$ & $66.7 \pm 6.8^{\mathrm{a}}(87)$ & $61.9 \pm 5.7^{\mathrm{a}}(81)$ \\
\hline Glutamine & $69.3 \pm 8.0^{\mathrm{a}}(100)$ & $84.4 \pm 10.4^{\mathrm{a}}(122)$ & $78.4 \pm 12.6^{\mathrm{a}}(113)$ & $81.9 \pm 21.7^{\mathrm{a}}(118)$ \\
\hline Asparagine & $79.3 \pm 7.5^{\mathrm{a}}(100)$ & $108.2 \pm 15.7^{\mathrm{a}}(136)$ & $91.5 \pm 18.7^{\mathrm{a}}(115)$ & $80.5 \pm 19.7^{\mathrm{a}}(102)$ \\
\hline TAA* & $2,702.3 \pm 17.2^{\mathrm{a}}(100)$ & $2,692.4 \pm 108.5^{\mathrm{a}}(100)$ & $2,729.5 \pm 102.0^{\mathrm{a}}(101)$ & $2,681.2 \pm 66.1^{\mathrm{a}}(99)$ \\
\hline
\end{tabular}

Values in parentheses are the percentage of the value at day 0 . Different letters indicate significant differences $(P<0.05)$. Values are means \pm standard deviation $(n=3)$.

TAA, total amount of free amino acids. 


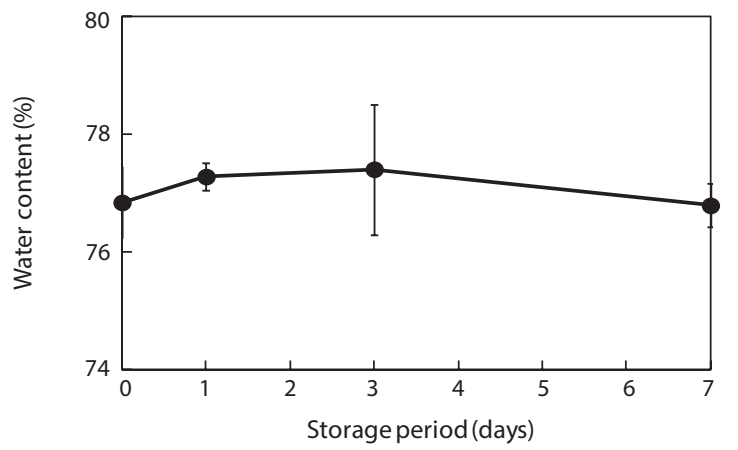

Fig. 2. Moisture content of shucked oysters during storage at $3^{\circ} \mathrm{C}$. The mean moisture content of oysters did not differ significantly during the storage period. The vertical bars represent standard deviations $(n=3)$.

After 7 days of storage, levels of aspartic acid and tyrosine significantly decreased and increased, respectively. Alanine levels increased by $122 \%(P=0.07)$. The total FAA content in the adductor muscle was $1,832.1 \mathrm{mg} / 100 \mathrm{~g}$ before storage. Taurine, glycine, proline, $\beta$-alanine, and glutamic acid were the most abundant FAAs in adductor muscle with respective concentrations of $892.4,242.4,145.9,129.9$, and 102.1

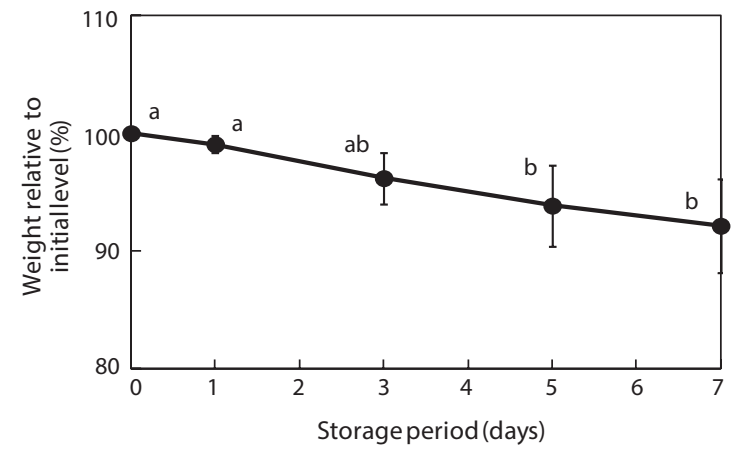

Fig. 3. Percentage change in weight of shucked oysters during storage at $3^{\circ} \mathrm{C}$. Different letters indicate significant differences $(p<0.05)$. The vertical bars represent standard deviations $(n=5)$.

$\mathrm{mg} / 100 \mathrm{~g}$ (Table 2). The total amount of FAAs in the adductor muscle decreased significantly throughout the storage period. All FAAs in the adductor muscle decreased to less than $80 \%$ of their initial levels after 7 days of storage. These reductions were statistically significant $(P<0.05)$ for the majority of FAAs. In addition, ammonia content increased significantly in the adductor muscle after 7 days $(P<0.05)$.

Table 2. Changes in free amino acids and ammonia in the adductor muscle of shucked oyster during storage at $3^{\circ} \mathrm{C}(\mathrm{mg} / 100 \mathrm{~g})$

\begin{tabular}{|c|c|c|c|c|}
\hline \multirow{2}{*}{ Amino acids } & \multicolumn{4}{|c|}{ Storage period (days) } \\
\hline & $\mathbf{0}$ & 1 & 3 & 7 \\
\hline Taurine & $892.4 \pm 119.7^{\mathrm{a}}(100)$ & $750.6 \pm 27.6^{\mathrm{a}}(84)$ & $617.2 \pm 65.4^{\mathrm{b}}(69)$ & $587.7 \pm 77.2^{\mathrm{b}}(66)$ \\
\hline Aspartic acid & $30.6 \pm 6.1^{\mathrm{a}}(100)$ & $17.9 \pm 2.3^{\mathrm{b}}(58)$ & $14.5 \pm 0.8^{\mathrm{b}}(47)$ & $12.0 \pm 2.3^{\mathrm{b}}(39)$ \\
\hline Threonine & $19.2 \pm 7.0^{\mathrm{a}}(100)$ & $14.7 \pm 1.0^{\mathrm{a}}(77)$ & $13.6 \pm 2.1^{\mathrm{a}}(71)$ & $10.4 \pm 3.1^{\mathrm{a}}(54)$ \\
\hline Serine & $10.3 \pm 2.0^{\mathrm{a}}(100)$ & $8.8 \pm 0.5^{\mathrm{ab}}(85)$ & $6.0 \pm 0.7^{\mathrm{bc}}(58)$ & $4.2 \pm 0.7^{\mathrm{c}}(41)$ \\
\hline Glutamic acid & $102.1 \pm 19.6^{\mathrm{a}}(100)$ & $75.9 \pm 3.4^{\mathrm{ab}}(74)$ & $60.7 \pm 2.5^{\mathrm{bc}}(59)$ & $45.9 \pm 5.3^{\mathrm{c}}(45)$ \\
\hline Proline & $145.9 \pm 19.5^{\mathrm{a}}(100)$ & $112.4 \pm 12.1^{\mathrm{ab}}(77)$ & $92.4 \pm 7.9^{\mathrm{bc}}(63)$ & $69.7 \pm 8.4^{\mathrm{c}}(48)$ \\
\hline Glycine & $242.4 \pm 12.2^{\mathrm{a}}(100)$ & $187.4 \pm 14.4^{\mathrm{b}}(77)$ & $118.2 \pm 24.7^{\circ}(49)$ & $110.6 \pm 17.5^{\mathrm{c}}(46)$ \\
\hline Alanine & $94.5 \pm 16.4^{\mathrm{a}}(100)$ & $78.0 \pm 5.6^{\mathrm{ab}}(82)$ & $65.7 \pm 1.5^{\mathrm{b}}(69)$ & $63.5 \pm 9.8^{\mathrm{b}}(67)$ \\
\hline Valine & $5.5 \pm 1.5^{\mathrm{a}}(100)$ & $4.6 \pm 0.4^{\mathrm{a}}(84)$ & $4.6 \pm 0.5^{\mathrm{a}}(84)$ & $4.2 \pm 1.3^{\mathrm{a}}(77)$ \\
\hline Cystine & $1.1 \pm 0.1^{\mathrm{a}}(100)$ & $1.0 \pm 0.0^{\mathrm{a}}(95)$ & $0.7 \pm 0.6^{\mathrm{a}}(60)$ & $0.3 \pm 0.6^{\mathrm{a}}(32)$ \\
\hline Methionine & $5.8 \pm 1.5^{\mathrm{a}}(100)$ & $4.6 \pm 1.0^{\mathrm{a}}(80)$ & $4.6 \pm 0.5^{\mathrm{a}}(79)$ & $3.5 \pm 0.4^{\mathrm{a}}(60)$ \\
\hline Isoleucine & $3.5 \pm 0.8^{\mathrm{a}}(100)$ & $3.0 \pm 0.1^{\mathrm{a}}(86)$ & $2.8 \pm 0.2^{\mathrm{a}}(81)$ & $2.6 \pm 0.6^{\mathrm{a}}(75)$ \\
\hline Leucine & $5.2 \pm 1.5^{\mathrm{a}}(100)$ & $4.2 \pm 0.3^{\mathrm{a}}(80)$ & $4.3 \pm 0.5^{\mathrm{a}}(82)$ & $3.9 \pm 1.4^{\mathrm{a}}(75)$ \\
\hline Tyrosine & $4.0 \pm 0.5^{\mathrm{a}}(100)$ & $3.3 \pm 0.3^{\mathrm{ab}}(82)$ & $3.2 \pm 0.3^{\mathrm{ab}}(79)$ & $2.9 \pm 0.4^{\mathrm{b}}(73)$ \\
\hline Phenylalanine & $2.5 \pm 0.5^{\mathrm{a}}(100)$ & $2.3 \pm 0.1^{\mathrm{a}}(91)$ & $2.2 \pm 0.5^{\mathrm{a}}(85)$ & $1.9 \pm 0.3^{\mathrm{a}}(76)$ \\
\hline$\beta$-Alanine & $129.9 \pm 16.3^{\mathrm{a}}(100)$ & $83.5 \pm 4.1^{\mathrm{b}}(64)$ & $74.3 \pm 8.1^{b}(57)$ & $58.0 \pm 12.8^{\mathrm{b}}(45)$ \\
\hline Ammonia & $2.6 \pm 0.3^{\mathrm{a}}(100)$ & $2.1 \pm 0.1^{\mathrm{a}}(82)$ & $2.2 \pm 0.1^{\mathrm{a}}(85)$ & $4.1 \pm 0.4^{\mathrm{b}}(156)$ \\
\hline Lysine & $7.3 \pm 1.6^{\mathrm{a}}(100)$ & $5.5 \pm 0.4^{\mathrm{a}}(76)$ & $6.5 \pm 3.1^{\mathrm{a}}(89)$ & $5.0 \pm 1.3^{\mathrm{a}}(69)$ \\
\hline Histidine & $11.1 \pm 2.7^{\mathrm{a}}(100)$ & $8.4 \pm 0.2^{\mathrm{ab}}(76)$ & $7.4 \pm 0.2^{\mathrm{ab}}(67)$ & $6.5 \pm 1.5^{\mathrm{b}}(58)$ \\
\hline Arginine & $73.0 \pm 6.5^{\mathrm{a}}(100)$ & $61.6 \pm 6.4^{\mathrm{a}}(84)$ & $48.6 \pm 6.0^{\mathrm{ab}}(67)$ & $44.6 \pm 5.1^{\mathrm{b}}(61)$ \\
\hline Glutamine & $16.7 \pm 8.1^{\mathrm{a}}(100)$ & $14.4 \pm 2.1^{\mathrm{a}}(86)$ & $12.8 \pm 2.2^{\mathrm{a}}(77)$ & $11.8 \pm 2.5^{\mathrm{a}}(71)$ \\
\hline Asparagine & $30.4 \pm 13.1^{\mathrm{a}}(100)$ & $21.3 \pm 3.5^{\mathrm{ab}}(70)$ & $15.1 \pm 2.5^{\mathrm{ab}}(50)$ & $11.0 \pm 2.6^{\mathrm{b}}(36)$ \\
\hline TAA* & $1,832.1 \pm 247.5^{\mathrm{a}}(100)$ & $1,462.2 \pm 59.7^{\mathrm{ab}}(80)$ & $1,174.5 \pm 75.6^{\mathrm{bc}}(64)$ & $1,059.9 \pm 150.4^{\mathrm{c}}(58)$ \\
\hline
\end{tabular}

Values in parentheses are the percentage of the value at day 0 . Different letters indicate significant differences $(P<0.05)$. Values are means \pm standard deviation $(n=3)$.

TAA, total amount of free amino acids. 


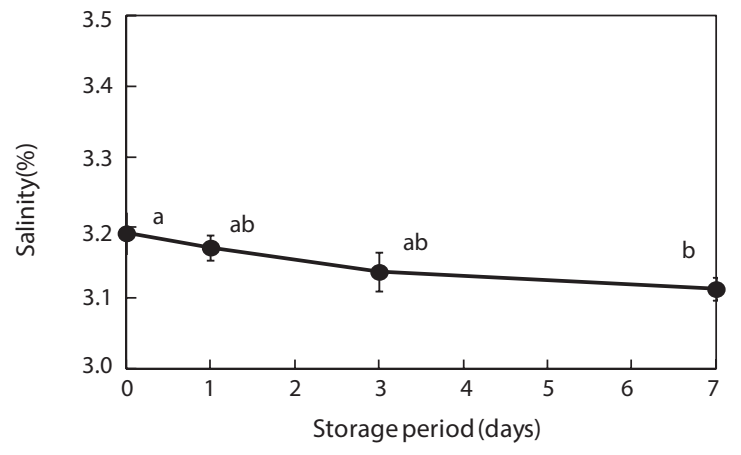

Fig. 4. Change in salinity of the salt water used for soaking oysters during storage at $3^{\circ} \mathrm{C}$. Different letters indicate significant differences $(P<$ $0.05)$. The vertical bars represent standard deviations $(n=3)$.

Ammonia and most of the FAAs were detected in the surrounding water after 7 days of storage at $3^{\circ} \mathrm{C}$ (Table 3 ). Of these, taurine was the most abundant $(370.6 \mathrm{mg} / 100 \mathrm{~g})$ followed by $\beta$-alanine, glutamic acid, and alanine, in that order. These FAAs were also abundant in the whole body and adductor muscle prior to storage.

Table 3. Free amino acids and ammonia in the soaking water after 7 day storage at $3^{\circ} \mathrm{C}$

\begin{tabular}{|c|c|}
\hline Amino acids & $\begin{array}{c}\mathrm{mg} / 100 \mathrm{~g} \\
\text { wet oyster tissue }\end{array}$ \\
\hline Taurine & $370.6 \pm 19.8$ \\
\hline Aspartic acid & N.D. \\
\hline Threonine & N.D. \\
\hline Serine & $0.2 \pm 0.0$ \\
\hline Glutamic acid & $20.4 \pm 7.2$ \\
\hline Proline & $11.3 \pm 2.4$ \\
\hline Glycine & $10.6 \pm 2.8$ \\
\hline Alanine & $19.5 \pm 0.9$ \\
\hline Valine & $0.5 \pm 0.1$ \\
\hline Cystine & $0.2 \pm 0.0$ \\
\hline Methionine & $0.1 \pm 0.1$ \\
\hline Isoleucine & $0.3 \pm 0.0$ \\
\hline Leucine & $0.1 \pm 0.0$ \\
\hline Tyrosine & $0.2 \pm 0.0$ \\
\hline Phenylalanine & N.D. \\
\hline$\beta$-Alanine & $54.8 \pm 3.7$ \\
\hline Ammonia & $15.7 \pm 2.1$ \\
\hline Lysine & $0.4 \pm 0.2$ \\
\hline Histidine & $2.3 \pm 0.1$ \\
\hline Arginine & $0.3 \pm 0.1$ \\
\hline Glutamine & N.D. \\
\hline Asparagine & N.D. \\
\hline TAA* & $491.7 \pm 19.3$ \\
\hline
\end{tabular}

Values are means \pm standard deviation $(n=3)$.

TAA, total amount of free amino acids.
Moisture content and weight of the shucked oysters changed during storage at $3^{\circ} \mathrm{C}$ (Figs. 2 and 3). Water content of the whole-body oysters remained relatively constant during the storage period while the whole-body weight decreased significantly. The mean individual body weight of the shucked oysters on day 0 was $20.7 \mathrm{~g}$. After 7 days of storage, the mean body weight was reduced by $92.1 \%$. Fig. 4 shows the associated changes in the salinity of the surrounding water. Before storage, the salinity was $3.19 \%$. Salinity decreased during storage, reaching a final level of $3.11 \%$ after 7 days.

\section{Discussion}

Glycogen levels in the whole bodies of shucked oysters remained relatively constant during the first 3 days of storage at $3^{\circ} \mathrm{C}$ but had shown a significant decrease after 7 days. This finding indicates that glycogen is utilized by shucked oysters during cold storage in seawater. Isani et al. (1995) reported that glycogen levels decreased in live mussels exposed to long-term (more than $24 \mathrm{~h}$ ) anoxic conditions. Similarly, Chiou et al. $(1998,2002)$ demonstrated that decreases in glycogen commonly occurred during storage at different temperatures $\left(0-30^{\circ} \mathrm{C}\right)$ in live hard clams, and that glycogen tended to decrease in live small abalones only during the late stages of storage.

Levels of nearly all of the FAAs remained unchanged during the storage period while the weight of the whole-body oysters decreased significantly. Together, these results indicate that the FAA content per oyster decreased during storage. In contrast, levels of aspartic acid and tyrosine significantly decreased and increased, respectively, after the 7 days of storage. In addition, levels of alanine in the oysters increased. FAA levels in bivalves are known to increase or decrease to enable these organisms to adapt to hypoxic/anoxic conditions or osmotic stress resulting from variations in their habitats (Lynch and Wood, 1966; Kluytmans et al., 1977; Heavers and Hammen, 1985; Isani et al., 1995; Enomoto et al., 1996; Hosoi et al., 2003; Rafrafi and Uglow, 2009). Murata and Sakaguchi (1986) reported that taurine and glycine levels in whole-body oysters changed very little during storage, alanine levels increased slightly, and proline and glutamic acid levels decreased. Therefore, changes in the levels of FAAs in shucked oysters can be attributed to storage conditions. Chiou et al. (1998) showed that the total amount of FAAs in live hard clams increased by $36 \%$ and $43 \%$ during storage at $5{ }^{\circ} \mathrm{C}$ and $10^{\circ} \mathrm{C}$, respectively. In addition, considerable increases in the total FAA content of the foot muscle of live small abalones have been observed during storage at $5-25^{\circ} \mathrm{C}$ (Chiou et al., 2002). Increases in the amounts of volatile basic nitrogen in small abalones (Chiou et al., 2002) and oysters (Murata and Sakaguchi, 1986) during storage was attributed to the initial stages of decomposition. However, in the current study, levels of ammonia in whole-body oysters remained nearly un- 
changed throughout the storage period. Thus, shucked oysters stored for 7 days at $3^{\circ} \mathrm{C}$ would most likely be acceptable for commercial use. Moreover, a previous study (Tanimoto et al., 2004) showed that the population of psychrotrophic bacteria in shucked oysters increased by only one order of colonyforming units per gram after 10 days of storage at $3^{\circ} \mathrm{C}$. In contrast, ammonia levels increased significantly in the adductor muscle after 7 days of storage $(P<0.05)$. Shucked oysters in the present study were prepared by cutting the adductor muscle to separate the whole-body oyster from the shell. This cutting may have affected the deamination of amino acids by enzymatic or microbial action. However, the root cause of the observed increases in ammonia content in the adductor muscle remains unclear.

The present study showed significant decreases in both the total amount of FAAs and in the amounts of the majority of individual FAAs in the adductor muscle during storage. Murata and Sakaguchi (1986) reported that in adductor muscles that had been removed from the whole body prior to storage, taurine and glycine levels remained unchanged, alanine levels increased markedly, and glutamic acid levels decreased during storage on ice. These results suggest that storage conditions can affect the FAA content of adductor muscles of shucked oysters. Enomoto et al. (1996) demonstrated a gradual decrease in the arginine level of adductor muscles in scallops in proportion to the acclimation time from aerobic to anaerobic conditions. Postmortem changes in the FAA levels of bivalve adductor muscles during storage were characterized by Wongso and Yamanaka (1996), who showed that in the noble scallops, the total amount of FAAs increased gradually until the onset of decomposition and then decreased. In addition, the changes and trends in the levels of FAAs in Japanese baking scallops were shown to vary among the different types of amino acids analyzed (Wongso and Yamanaka, 1998). These data suggest that the changes in FAA levels in the adductor muscles of bivalves depend not only on the species but also on the storage method(s). In the present study, most of the target FAAs were detected in the soaking water after 7 days of storage. In a previous study (Tanimoto et al., 2004), the total amount of ATP and its related compounds decreased rapidly in the adductor muscles of shucked oysters during 1 day of storage and slowly decreased thereafter. This reduction was larger than that observed in adductor muscles that had been removed from the whole body before storage at $5^{\circ} \mathrm{C}$ (Yokoyama et al., 1994). In contrast, shucked oysters for the present study were prepared by cutting the adductor muscle from the shell prior to soaking the oysters in salt water. Note that the salinity of the salt water used for soaking these shucked oysters decreased during storage at $3{ }^{\circ} \mathrm{C}$. Thus, the observed decreases in FAA levels in the adductor muscles of shucked oysters under our storage conditions may have resulted from the elution of FAAs from the cut surface of the adductor muscle.

FAAs are known to be important contributors to the flavor of fish and shellfish (Konosu and Yamaguchi, 1982). Taurine, glycine, alanine, glutamic acid, and arginine are the major constituents of shellfish and considered to be the active taste components in abalones (Konosu, 1973), scallops (Konosu et al., 1988), and short-necked clams (Fuke and Konosu, 1989). When FAA levels in the adductor muscle of shucked oysters were compared with FAA taste thresholds (Yoshida et al., 1966; Schiffman et al., 1979), the prestorage levels of aspartic acid, glutamic acid, glycine, alanine, cystine, lysine, histidine, arginine, and asparagine were all higher than their respective taste threshold levels. After storage, however, glycine, lysine, and asparagine levels fell below their respective taste threshold levels. Therefore, the taste of adductor muscles of shucked oysters that have been soaked in salt water may change during cold storage.

\section{Acknowledgements}

The authors are grateful to Dr Ohta Kohei, South Ehime Fisheries Research Center, Ehime University, for preparation of shucked oysters.

\section{References}

Blaedel WJ and Meloche VW. 1960. Elementary Quantitative Analysis. Harper and Row, New York, US.

Chiou TK, Lin JF and Shiau CY. 1998. Changes in extractive components and glycogen in the edible meat of hard clam Meretrix lusoria during storage at different temperatures. Fish Sci 64, 115-120.

Chiou TK, Lai MM, Lan HL and Shiau CY. 2002. Extractive component changes in the foot muscle of live small abalone during storage. Fish Sci 68, 380-387.

Da Silva RSM and Zancan DM. 1994. Seasonal variation of the carbohydrate and lipid metabolism in a land pulmonate gastropod, Megalobulimus oblongus. Comp Biochem Physiol A Physiol 108, 337-341.

Enomoto T, Takizawa H and Ohyama H. 1996. Changes in umami-related metabolites during acclimation of aerobic scallop (Patinopecten yessoensis Jay) to anaerobiosis. Nippon Eiyo Shokuryo Gakkaishi 49, 349-353.

Fuke S and Konosu S. 1989. Taste-active components of a few species of bivalves. In: Society for Research on Umami Taste '89 Forum. Kawamura Y, ed. Society for Umami Research on Umami Taste, Tokyo, JP, pp. 85-91.

Hashimoto Y. 1965. Taste-producing substances in marine products. In: The Technology of Fish Utilization. Kreuzer R, ed. Fishing News (Books) Inc., London, GB, pp. 57-61.

Heavers BW and Hammen CS. 1985. Fate of endogenous free amino acids in osmotic adjustment of Crassostrea virginica (Gmelin). Comp Biochem Physiol A Physiol 82, 571-576.

Hosoi M, Kubota S, Toyohara M, Toyohara H and Hayashi I. 2003. Effect of salinity change on free amino acid content in Pacific oyster. Fish Sci 69, 395-400. 
Isani G, Cattani O, Zurzolo M, Pagnucco C and Cortesi P. 1995. Energy metabolism of the mussel, Mytilus galloprovincialis, during longterm anoxia. Comp Biochem Physiol B Biochem Mol Biol 110, 103-113.

Kluytmans JH, De Bont AMT, Janus J and Wijsman TCM. 1977. Time dependent changes and tissue specificities in the accumulation of anaerobic fermentation products in the sea mussel Mytilus edulis $\mathrm{L}$. Comp Biochem Physiol B Comp Biochem 58, 81-87.

Konosu S. 1973. Taste of fish and shellfish with special reference to taste-producing substances. Nippon Shokuhin Kogyo Gakkaishi 20, 432-439.

Konosu S and Yamaguchi K. 1982. The flavor components in fish and shellfish. In: Chemistry and Biochemistry of Marine Food Products. Martin RE, Flick GJ, Hebard CE and Ward DE, eds. AVI Publishing, Westport, CT, US, pp. 367-404.

Konosu S, Watanabe K, Koriyama T, Shirai T and Yamaguchi K. 1988. Extractive components of scallop and identification of its taste-active components by omission test. Nippon Shokuhin Kogyo Gakkaishi 35, 252-258.

Lynch MP and Wood L. 1966. Effects of environmental salinity of free amino acids of Crassostrea virginica gmelin. Comp Biochem Physiol 19, 783-790.

Murata M and Sakaguchi M. 1986. Changes in contents of free amino acids, trimethylamine, and nonprotein nitrogen of oyster during ice storage. Nippon Suisan Gakkaishi 52, 1975-1980.

Ogunsua AO, Ariahu CC and Adebona MB. 1990. Post-harvest changes in periwinkle (Tympanostomus fuscatus) at tropical ambient storage conditions. Lebensmittel-Wiss Technol 23, 343-348.

Okumura T, Nagasawa T, Hayashi I and Sato Y. 2002. Effects of starvation on RNA : DNA ratio, glycogen content, and $\mathrm{C}: \mathrm{N}$ ratio in columellar muscle of the Japanese turban shell Turbo (Batillus) cornutus (Gastropoda). Fish Sci 68, 306-312.

Patrick S, Faury N and Goulletquer P. 2006. Seasonal changes in carbohydrate metabolism and its relationship with summer mortality of Pacific oyster Crassostrea gigas (Thunberg) in Marennes-Oléron bay (France). Aquaculture 252, 328-338.
Rafrafi S and Uglow RF. 2009. Nitrogenous compounds changes in emersed oysters: Crassostrea gigas. Estuar Coast Shelf Sci 81, 210214.

Schiffman SS, Hornack K and Reilly D. 1979. Increased taste thresholds of amino acids with age. Am J Clin Nutr 32, 1622-1627.

Shinkawa H. 1988. Biology of Oyster. Eibunsha, Tokyo, JP, pp. 98-109. Tanimoto S, Aoyama Y and Okazaki T. 2004. Changes in ATP and its related compounds and organic acid in oyster soaked in salt water at $3^{\circ} \mathrm{C}$. Bull Hiroshima Prefect Food Technol Res Center 23, 9-14.

Uzaki N, Kai M, Aoyama H and Suzuki T. 2003. Changes in mortality rate and glycogen content of the Manila clam Ruditapes philippinarum during the development of oxygen-deficient waters. Fish Sci 69, 936-943.

Wongso S and Yamanaka H. 1996. Changes in content of extractive components in the adductor muscle of noble scallop during storage. Fish Sci 62, 815-820.

Wongso S and Yamanaka H. 1998. Extractive components of the adductor muscle of Japanese baking scallop and changes during refrigerated storage. J Food Sci 63, 772-776.

Wu G. 2009. Amino acids: metabolism, functions, and nutrition. Amino Acids 37, 1-17.

Wu G. 2010. Functional amino acids in growth, reproduction, and health. Adv Nutr 1, 31-37.

Yokoyama Y, Sakaguchi M, Kawai F and Kanamori M. 1994. Effects of storage temperature on postmortem changes of ATP and its related compounds and freshness indices in oyster tissues. Fish Sci 60, 217-223.

Yoshida M, Ninomiya T, Ikeda S, Yamaguchi S, Yoshikawa T and Ohara M. 1966. Studies on the taste of amino acids. Part I. Determination of threshold values of various amino acids. Nippon Nōgeikagaku Kaishi 40, 295-299.

Zandee DI, Kluytmans JH, Zurburg W and Pieters H. 1980. Seasonal variations in biochemical composition of Mytilus edulis with reference to energy metabolism and gametogenesis. Neth J Sea Res 14, 1-29. 